\title{
KEDUDUKAN ASAS KEADILAN BERIMBANG DALAM HUKUM KEWARISAN ISLAM DIKAITKAN DENGAN PERATURAN MAHKAMAH AGUNG R.I. NOMOR 3 TAHUN 2017 TENTANG PEDOMAN MENGADILI PERKARA PEREMPUAN BERHADAPAN DENGAN HUKUM
}

\author{
Haniah Ilhami* \\ Departemen Hukum Islam, Fakultas Hukum, Universitas Gadjah Mada \\ Jl. Sosio Yustisia Bulaksumur, No. 1, Karangmalang, Kab. Sleman, D. I. Yogyakarta 55281
}

\begin{abstract}
Identifying the interrelation between the Principle of Equality of Justice in Islamic Inheritance Law and the Principle of Non-discrimination in Supreme Court Regulation Number 3 years 2017 concerning Guidance on Presecuting Legal Cases Involving Women, this normative research conducts legal comparisons using a conceptual approach. This research finds the independence the Principle of Equality of Justice, due to the application of the principle which is not determined by the Supreme Court Regulation No.3 / 2017. Furthermore, the principle does not substantially contradict with the Principle of Non-discrimination.

Keywords: Principle of Equality of Justice, Supreme Court Regulation Number 3 year 2017 concerning Guidance on Presecuting Legal Cases Involving Women, Equality of Right and Obligation
\end{abstract}

\section{Intisari}

Penelitian ini didasarkan pada adanya persinggungan antara Asas Keadilan Berimbang dengan konsep non diskriminasi yang diusung oleh PERMA No. 3/2017. Asas Keadilan Berimbang membedakan bagian antara ahli waris perempuan dan ahli waris laki-laki, sementara PERMA No.3/2017 melarang hakim untuk melakukan pembedaan ataupun pembatasan yang dibuat atas dasar jenis kelamin yang mempunyai dampak mengurangi hak-hak tertentu bagi para pihak yang berperkara di pengadilan. Penelitian bertujuan untuk mengkaji kedudukan asas Keadilan Berimbang dalam penyelesaian perkara waris Islam pasca ditetapkannya PERMA No. 3/2017. Penelitian ini merupakan penelitian hukum normatif dalam bentuk perbandingan hukum dengan menggunakan pendekatan konseptual (conceptual approach) Penelitian menyimpulkan bahwa Asas Keadilan Berimbang merupakan asas yang independen karena penerapan dan penegakannya tidak bergantung serta tidak bertentangan dengan prinsip Non Diskriminasi yang diatur dalam PERMA No.3/2017.

Kata Kunci: Asas Keadilan Berimbang, Peraturan Mahkamah Agung Nomor 3 tahun 2017 tentang Pedoman Mengadili Perempuan Berhadapan dengan Hukum, Keseimbangan Hak dan Kewajiban

\section{Pokok Muatan}

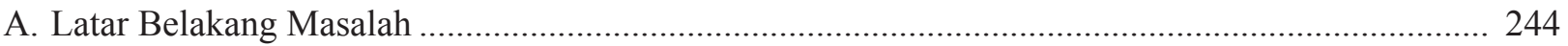

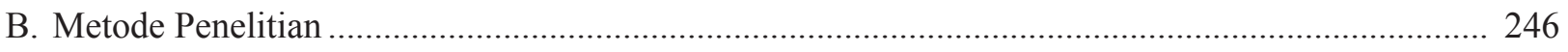

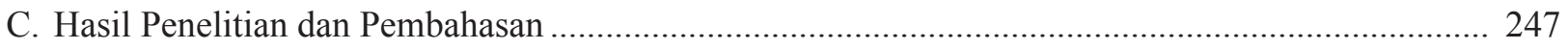

1. Kedudukan Asas Keadilan Berimbang dalam Sistem Hukum Waris Islam di Indonesia............. 247

2. Kedudukan Peraturan Mahkamah Agung Nomor 3 tahun 2017 tentang Pedoman Mengadili Perkara Perempuan Berhadapan dengan Hukum dalam Penyelesaian Perkara Waris Islam ....... 252

3. Asas Keadilan Berimbang Dikaitkan dengan Peraturan Mahkamah Agung Nomor 3 tahun 2017 tentang Pedoman Mengadili Perkara Perempuan Berhadapan dengan Hukum dalam Penyelesaian Perkara Waris Islam ................................................................................ 253

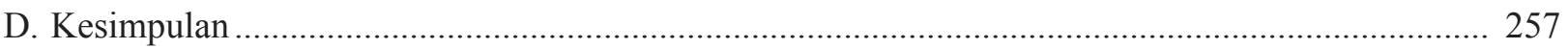

\footnotetext{
* Alamat korespondensi: haniah.ilhami@gmail.com.
} 


\section{A. Latar Belakang Masalah}

Asas Keadilan Berimbang merupakan salah satu pondasi dasar dalam Hukum Kewarisan Islam. Bersama dengan beberapa asas lainnya, asas ini memberikan bentuk dan karakteristik hukum kewarisan Islam yang membedakannya dengan sistem hukum kewarisan lain, seperti hukum kewarisan adat dan hukum kewarisan berdasarkan Burgerlijk Wetboek (BW) yang berlaku di Indonesia. ${ }^{1}$ Secara teoritis, Asas Keadilan Berimbang mengandung pengertian bahwa harus senantiasa terdapat keseimbangan antara hak dan kewajiban, antara yang diperoleh seseorang dengan kewajiban yang harus ditunaikan. Laki-laki dan perempuan akan mendapat hak yang sebanding dengan kewajiban yang dipikulnya masing-masing kelak dalam kehidupan keluarga dan masyarakat. ${ }^{2}$ Dalam sistem hukum kewarisan Islam, harta peninggalan/warisan yang diterima oleh ahli waris, pada prinsipnya bertujuan untuk kelanjutan tanggung jawab masing-masing terhadap keluarga. Laki-laki memiliki kewajiban ganda, yaitu tehadap dirinya dan keluarganya, sehingga bagian harta warisnya pun akan mengikuti besarnya tanggung jawab tersebut. ${ }^{3}$ Sementara secara praktis, asas ini didefinisikan sebagai asas yang mengatur besar porsi yang diterima ahli waris yang berhak dengan perbandingan bagian laki-laki adalah 2 (dua) kali lipat dari bagian perempuan. ${ }^{4}$

Hukum Kewarisan Islam di Indonesia mengadopsi Asas Keadilan Berimbang. Asas ini secara konseptual pertama kali diformalkan dalam Kompilasi Hukum Islam (selanjutnya disebut KHI), khususnya pada Bab III Buku II yang secara keseluruhan mengatur tentang besarnya bagian yang akan diterima masing-masing ahli waris yang berhak. ${ }^{5}$ KHI memang tidak menggunakan terminologi tekstual Asas Keadilan Berimbang, namun rincian porsi bagian masing-masing ahli waris sudah menerapkan asas tersebut ${ }^{6}$. Istilah Asas Keadilan Berimbang secara teknis baru digunakan dalam Buku II Pedoman Teknis Administrasi dan Teknis Peradilan Agama yang disusun oleh Mahkamah Agung (selanjutnya disebut Buku II MA) sebagai pedoman proses litigasi di Pengadilan Agama. ${ }^{7}$ Kedua regulasi inilah yang menjadi dasar hukum bagi Asas Keadilan Berimbang dan sekaligus memberikan kekuatan mengikat terhadap asas tersebut dalam sistem hukum Indonesia.

Kedua regulasi tersebut di atas juga mengatur penegakan Asas Keadilan Berimbang secara yuridis formal dalam proses litigasi di Pengadilan Agama. Buku II MA yang merupakan salah satu ketentuan hukum formil beracara di pengadilan, menetapkan bahwa hukum materiil yang digunakan dalam penyelesaian perkara waris di Pengadilan Agama adalah hukum kewarisan KHI dan yurisprudensi yang bersumber dari Al qur'an, hadis, dan ijtihad. ${ }^{8}$ Untuk itu maka seluruh proses persidangan perkara kewarisan dilakukan dengan menegakkan dan mengimplementasikan asas-asas waris Islam, termasuk di dalamnya Asas Keadilan Berimbang. ${ }^{9}$

Lihat Amir Syarifuddin, 2008, Hukum Kewarisan Islam, Kencana, Jakarta, hlm.17.

Muhammad Daud Ali, 2011, Hukum Islam : Pengantar Ilmu Hukum dan Tata Hukum Islam di Indonesia, Rajawali Pers, Jakarta, hlm.143.

Lihat Syamsulbahri Salihima, 2015, Perkembangan Pemikiran Pembagian Warisan dalam Hukum Islam dan Implementasinya pada Pengadilan Agama, Kencana, Jakarta, hlm. 47.

4 Lihat Pedoman Khusus Hukum Kewarisan angka 2 huruf e Mahkamah Agung, 2013, Buku II Pedoman Teknis Administrasi dan Teknis Peradilan Agama, Mahkamah Agung, Jakarta.

Secara khusus, hal ini diatur dalam pasal 176 sampai dengan 182 Kompilasi Hukum Islam.

6 Misalnya pada pasal 176 ditegaskan bahwa “... apabila anak perempuan bersama-sama dengan anak laki-laki, maka bagian anak laki-laki adalah dua berbanding satu dengan anak perempuan."

Buku II Pedoman Teknis Administrasi dan Teknis Peradilan Agama merupakan pedoman teknis proses litigasi dalam lingkup Pengadilan Agama yang dikeluarkan oleh Mahkamah Agung. Pada tahun 2006, Mahkamah Agung memandang perlu untuk menyusun suatu pedoman pelaksanaan Tugas dan Administrasi Pengadilan secara mantap, jelas, dam tegas. Untuk itu, Mahkamah Agung kemudian membentuk suatu tim yang disebut sebagai Tim Penyempurnaan Buku I, Buku II, Buku III dan Buku tentang Pengawasan guna menyusun Pedoman yang dimaksud. Tim kemudian berhasil menyusun Pedoman yang dimaksud. Khusus terkait dengan pelaksanaan tugas dan administrasi pengadilan, pedoman ini lebih dikenal dengan istilah Buku II MA.

8 Lihat Pedoman Khusus Hukum Kewarisan angka (1) pada Mahkamah Agung, 2013, Buku II Pedoman Teknis Administrasi dan Teknis Peradilan Agama, Mahkamah Agung, Jakarta.

$9 \quad$ Lihat Pedoman Khusus Hukum Kewarisan angka (2) pada Ibid. 
Hakim harus mempertimbangkan dan menerapkan asas-asas waris Islam sebagai pedoman dalam melakukan pemeriksaan perkara waris, termasuk dalam penyusunan putusan. Sebagai contoh misalnya, ketika ada 1 (satu) sengketa waris yang diajukan ke Pengadilan Agama, maka hakim akan menggunakan asas Keadilan Berimbang untuk menyelesaikan sengketa tersebut saat memutuskan besar bagian pada ahli waris yang berhak, dengan memberikan bagian ahli waris laki-laki 2 (dua) kali lebih besar dibandingkan bagian ahli waris perempuan. Inilah kemudian yang menunjukkan kekuatan mengikat Asas Keadilan Berimbang dalam pelaksanaan hukum formiil melalui ketentuan beracara di Pengadilan Agama.

Implementasi Asas Keadilan Berimbang dalam proses litigasi pada saat yang sama juga terikat dengan regulasi-regulasi lain yang berlaku di lingkungan peradilan, di antaranya adalah Peraturan Mahkamah Agung Nomor 3 tahun 2017 tentang Pedoman Mengadili Perkara Perempuan Berhadapan dengan Hukum (selanjutnya disebut PERMA No. 3/2017). ${ }^{10}$ Secara umum, PERMA No.3/2017 merupakan pedoman bagi hakim ketika memeriksa perkara yang melibatkan Perempuan Berhadapan dengan Hukum. ${ }^{11}$ Melalui PERMA No.3/2017 ini, hakim diharapkan dapat memahami dan menerapkan kesetaraan gender dan prinsipprinsip non-diskriminasi dalam mengadili suatu perkara. ${ }^{12}$ Dalam upaya mewujudkan hal tersebut, PERMA No.3/2017 menetapkan asas-asas yang berlaku dalam dalam mengadili perkara Perempuan
Berhadapan dengan Hukum, yaitu: ${ }^{13}$ 1) Penghargaan atas harkat dan martabat manusia; 2) Non diskriminasi; 3) Kesetaraan Gender; 4) Persamaan di depan hukum; 5) Keadilan; 6) Kemanfaatan; dan 7) Kepastian Hukum

Pelaksanaan asas-asas tersebut kemudian dijabarkan dalam berbagai aturan tentang pedoman perilaku hakim dalam melakukan proses persidangan. PERMA No.3/2017 mengatur setidaknya 2 (dua) kategori acuan etika dan perilaku hakim saat memeriksa perkara, yaitu acuan tentang tindakan yang harus dilakukan oleh hakim dan tindakan harus dihindari ketika menghadapi perkara yang melibatkan Perempuan Berhadapan dengan Hukum. Apabila dikaitkan dengan Asas Keadilan Berimbang, muncul persinggungan antara konsep asas Keadilan Berimbang dengan pedoman tindakan dimaksud, yaitu pada ketentuan tentang: Pertama, Hakim tidak boleh membenarkan terjadinya diskriminasi terhadap perempuan dengan menggunakan kebudayaan, aturan adat, dan praktik tradisional lainnya maupun menggunakan penafsiran ahli yang bias gender. ${ }^{14}$ Kedua, hakim harus mempertimbangkan kesetaraan gender dan stereotip gender dalam peraturan perundangundangan dan hukum tidak tertulis. ${ }^{15}$ Ketiga, hakim harus melakukan penafsiran peraturan perundangundangan dan/atau hukum tidak tertulis yang dapat menjamin kesetaraan gender. ${ }^{16}$

Khusus untuk perkara kewarisan, ketiga hal tersebut diwujudkan dalam tindakan Hakim yang memandang semua anak, apapun jenis kelaminnya,

Berita Negara Republik Indonesia Tahun 2017 Nomor 1084 tanggal 4 Agustus 2017.

Peraturan Mahkamah Agung Nomor 3 tahun 2017 tentang Pedoman Mengadili Perkara Perempuan Berhadapan dengan Hukum menjelaskan bahwa Perempuan Berhadapan dengan Hukum adalah perempuan yang berkonflik dengan hukum, perempuan sebagai korban, perempuan sebagai saksi atau perempuan sebagai pihak.

Ibid. hlm.10.

3 Pasal 2 Peraturan Mahkamah Agung Nomor 3 tahun 2017 tentang Pedoman Mengadili Perkara Perempuan Berhadapan dengan Hukum.

14 Pasal 5 huruf (b) PERMA No. 3 tahun 2017 tentang Pedoman Mengadili Perkara Perempuan Berhadapan dengan Hukum. PERMA kemudian mengatur definisi Diskriminasi terhadap Perempuan adalah segala pembedaan, pengucilan atau pembatasan yang dibuat atas dasar jenis kelamin yang mempunyai dampak atau tujuan untuk mengurangi atau meniadakan pengakuan, penikmatan, atau penggunaan hak asasi manusia dan kebebasan-kebebasan pokok di bidang hukum, politik, ekonomi, sosial, bidaya, sipil atau bidang lainnya oleh perempuan, terlepas dari status perkawinan mereka atas dasar kesetaraan antara laki-laki dan perempuan.

15 Pasal 6 huruf (a) PERMA No. 3 tahun 2017 tentang Pedoman Mengadili Perkara Perempuan Berhadapan dengan Hukum. PERMA kemudian mengatur definisi Kesetaraan Gender adalah kesamaan dan keseimbangan kondisi antara laki-aki dan perempuan untuk memperoleh kesempatan dan hak-haknya sebagai manusia agar mampu berperan dan berpartisipasi di berbagai bidang. Sementara Steretip Gender diartikan sebagai pandangan umum atau kesan tentang atribut atau karakteristik yang seharusnya dimiliki dan diperankan perempuan dan laki-laki.

16 Pasal 6 huruf (b) PERMA No. 3 tahun 2017 tentang Pedoman Mengadili Perkara Perempuan Berhadapan dengan Hukum. 
setara dalam menerima keadilan. Hakim juga harus memandang bahwa anak perempuan berhak mendapatkan keadilan tanpa prasangka bahwa derajatnya lebih rendah dari anak laki-laki, sehingga merepa mendapatkan haknya secara adil tanpa adanya anggapan bahwa setiap anak perempuan akan mendapatkan bagian dari suaminya sehingga mereka dianggap layak memperoleh bagian lebih kecil daripada saudara laki-lakinya. ${ }^{17}$

Kondisi inilah yang menyebabkan lahirnya persinggungan antara Asas Keadilan Berimbang dengan konsep non diskriminasi yang diusung oleh PERMA No. 3/2017. Berdasarkan Asas Keadilan Berimbang, pembagian harta waris dilakukan dengan membedakan bagian antara ahli waris perempuan dan ahli waris laki-laki. Di sisi lain, PERMA No.3/2017 justru melarang hakim untuk melakukan pembedaan ataupun pembatasan yang dibuat atas dasar jenis kelamin yang mempunyai dampak mengurangi hak-hak tertentu bagi para pihak yang berperkara di pengadilan. Padahal keduanya, baik Asas Keadilan Berimbang maupun konsep non diskriminasi dalam PERMA No. 3/2017 sama-sama memiliki kekuatan mengikat khususnya dalam penyelesaian perkara waris di Pengadilan Agama.

Perkembangan inilah yang akan menjadi fokus permasalahan yang dijawab melalui penelitian ini. Berdasarkan pemaparan di atas, terlihat adanya persinggungan antara asas Keadilan Berimbang dalam hukum waris Islam dengan PERMA No. 3/2017 khususnya terkait prinsip Non Diskriminasi dalam mengadili perkara kewarisan yang melibatkan Perempuan Berhadapan dengan Hukum. Untuk itu, penelitian ini berusaha mengkaji bagaimana sebenarnya kedudukan asas Keadilan Berimbang dalam penyelesaian perkara waris Islam, khususnya pasca ditetapkannya PERMA No. 3/2017. Guna menjawab hal tersebut, penelitian dimulai melalui kajian komprehensif tentang kedudukan dan kekuatan mengikat asas Keadilan Berimbang dalam sistem hukum Indonesia, lalu dilanjutkan dengan kajian tentang kedudukan PERMA No.3/2017 dalam penyelesaian perkara waris Islam di Pengadilan Agama. Hasil dari kedua kajian tersebut kemudian dielaborasi dalam bentuk analisa untuk menjawab kedudukan Asas Keadilan Berimbang setelah ditetapkannya PERMA No. $3 / 2017$.

\section{B. Metode Penelitian}

Penelitian ini merupakan penelitian hukum normatif dalam bentuk perbandingan hukum dengan membandingkan 3 (tiga) unsur pokok, yaitu: ${ }^{18}$ Pertama, Struktur hukum, yang mencakup lembaga-lembaga hukum. Dalam penelitian ini, struktur yang dimaksud adalah lembaga peradilan khususnya Peradilan Agama. Kedua, substansi hukum, yang mencakup perangkat kaidah dan perilaku teratur. Dalam penelitian ini, kaidah yang dimaksud adalah Asas Keadilan Berimbang dalam hukum kewarisan Islam di Indonesia. Ketiga, budaya hukum, yang menyangkut perangkat nilainilai yang dianut. Dalam penelitian ini, nilai yang dimaksud adalah nilai keadilan dalam hukum waris Islam, serta nolai non diskriminasi dalam PERMA No.3/2017.

Penelitian ini menggunakan pendekatan konseptual(Conceptual approach) yaitu pendekatan yang beranjak dari pandangan-pandangan para sarjana dan doktrin-doktrin yang berkembang di dalam ilmu hukum untuk menunjang penyelesaian masalah yang dibahas. ${ }^{19}$ Pendekatan konseptual menganalisis konsep-konsep dari pengertian hukum, asas hukum, kaedah hukum, sistem hukum, dan berbagai konsep yuridis lainnya. ${ }^{20}$ Ada 2 (dua) tujuan yang ingin dicapai dalam pendekatan ini, yaitu untuk memperoleh makna baru atas suatu

Mahkamah Agung, MaPPI FHUI, dan AIPJ 2, 2018, Pedoman Mengadili Perkara Perempuan Berhadapan dengan Hukum, Mahkamah Agung R.I. dan AIPJ2, Jakarta, hlm. 45.

Bambang Sunggono, 1997, Metodologi Penelitian Hukum, RajaGrafindo Persada, Jakarta, hlm. 98.

Peter Mahmud Marzuki, 2011, Penelitian Hukum, Kencana Prenada Media Group, Jakarta, hlm. 177.

Hajar, 2017, Model-model Pendekatan dalam Penelitian Hukum dan Fiqh, Kalimedia, Yogyakarta, hlm. 90. 
konsep hukum, atau menguji konsep dan istilah hukum dalam teori dan praktik. ${ }^{21}$ Dikaitkan dengan rumusan permasalahan, maka tujuan dari pendekatan konseptual dalam penelitian ini adalah untuk menguji konsep asas Keadilan Berimbang dalam teori dan putusan Pengadilan Agama.

Penelitian dilakukan dengan menganalisa data sekunder yang meliputi dokumen-dokumen hukum resmi, hasil penelitian terdahulu, dan bahanbahan pustaka lainnya. Untuk dokumen hukum resmi, peneliti mengkaji bahan hukum primer yang bersifat mengikat dan berhubungan erat dengan pemasalahan yang diteliti, meliputi peraturan perundang-undangan, Keputusan Ketua Mahkamah Agung, Surat Edaran, dan Putusan Mahkamah Agung Republik Indonesia. Terhadap data-data tersebut, dilakukan analisa kualitatif, di mana semua data yang berhasil dikumpulkan langsung diteliti, dipilih, dan dipelajari secara utuh sehingga menghasilkan uraian yang bersifat deskriptif analisis, yaitu penjabaran dan penggambaran hal-hal yang berkaitan dengan masalah yang diteliti untuk kemudian dikaji sehingga didapatkan jawaban atas permasalahan yang ditetapkan.

\section{Hasil Penelitian dan Pembahasan}

Penerapan asas Keadilan Berimbang dalam ranah litigasi dihadapkan dengan regulasi pada hukum acara di Pengadilan Agama, termasuk di antaranya adalah PERMA No.3/2017. Setelah melakukan analisa tentang keterkaitan kedua ketentuan tersebut, penelitian ini menyimpulkan bahwa asas Keadilan Berimbang merupakan ketentuan dasar yang mandiri dan penerapannya tidak bergantung pada PERMA No.3/2017. Hal tersebut didasarkan pada analisis peneliti tentang masing-masing kedudukan Asas Keadilan Berimbang dan PERMA No.3/2017 dalam penyelesaian sengketa waris di Pengadilan, yang secara rinci dijelaskan sebagai berikut.

\section{Kedudukan Asas Keadilan Berimbang dalam Sistem Hukum Waris Islam di Indonesia}

Asas Keadilan Berimbang dalam kajian literatur mengandung 2 (dua) pengertian mendasar tentang pembagian harta waris di antara ahli waris yang berhak. Pengertian pertama adalah adanya penegasan bahwa perbedaan gender tidak menentukan hak kewarisan dalam Islam. Perempuan memiliki hak yang sama kuatnya dalam mendapatkan warisan sebagaimana yang didapatkan oleh laki-laki. ${ }^{22}$ Di sisi lain, laki-laki dan perempuan juga dapat mewarisi, dari orang tuanya atau keluarga dekatnya, baik ia keturunan laki-laki atau garis keturunan perempuan. ${ }^{23} \mathrm{Hal}$ ini terutama membedakan hukum kewarisan Islam dengan hukum kewarisan adat, khususnya yang berlandaskan pada sistem kekeluargaan tertentu. Sistem patrilineal, sebagai contoh, mengatur bahwa ahli waris yang berhak menerima harta waris hanyalah keturunan laki-laki saja/garis kebapakan.

Sementara dalam pengertian kedua, Asas Keadilan Berimbang mengatur besaran bagian masing-masing ahli waris yang berhak secara berimbang. Berimbang diartikan bahwa ahli waris laki-laki dan perempuan, masing-masing akan mendapat hak yang sebanding dengan kewajiban yang dipikulnya dalam kehidupan keluarga dan masyarakat. ${ }^{24}$ Dalam sistem kewarisan Islam, harta peninggalan yang diterima oleh ahli waris pada hakikatnya adalah pelanjutan tanggung jawab pewaris terhadap keluarganya, sehingga perbedaan tanggung jawab akan menentukan juga bagian harta waris yang diterima. Mengacu pada ketentuan hukum perkawinan Islam, seorang laki-laki menjadi penanggung jawab kehidupan keluarga, mencukupi keperluan hidup dan istrinya, sehingga sebagai

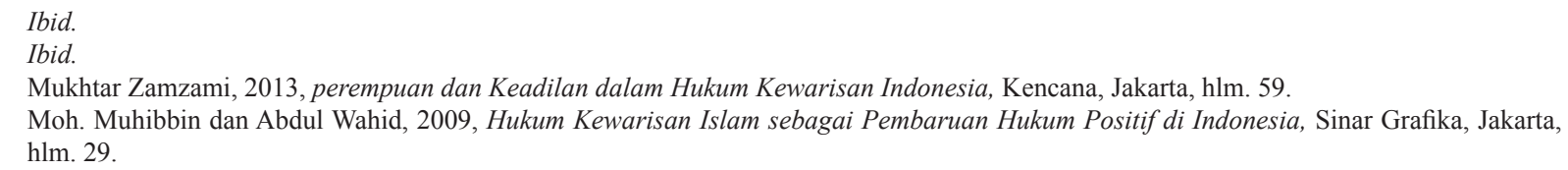


lanjutan dari tanggung jawab tersebut, maka melalui Asas Keadilan Berimbang, ahli waris lakilaki akan mendapatkan bagian yang lebih banyak dari perempuan.

Penerapan konsep berimbang tersebut diwujudkan dalam pengaturan rinci menganai jumlah bagian yang akan diterima oleh masing-masing ahli waris yang berhak. Asas Keadilan Berimbang pada prinsipnya mengatur adanya perbedaan jumlah bagian harta waris antara perempuan dan lakilaki ini didasarkan pada ketentuan Alquran surat An Nisaa ayat 11 dan 12. Berdasarkan kedua ayat tersebut, maka perbedaan bagian masing-masing ahli waris dapat disimpulkan sebagai berikut: ${ }^{25} 1$ ) Untuk bagian anak dari Pewaris, ditentukan bahwa bagian 1 (satu) anak laki-laki sama dengan bagian 2 (dua) anak perempuan; 2) Untuk orang tua dari Pewaris, apabila Pewaris tidak memiliki anak, maka Ibu akan mendapat $1 / 3$ dari harta warisan, dan ayah akan mendapat sisanya; 3) Untuk suami atau istri dari pewaris apabila pewaris tidak memiliki anak, maka Suami akan mendapat 1 1 2 sementara Istri akan mendapat $1 / 4$; 4) Untuk suami atau istri dari pewaris apabila pewaris memiliki anak, maka Suami akan mendapat $1 / 4$ sementara istri akan mendapat $1 / 8$.

Konsep yang sama juga berlaku dalam sistem hukum waris Islam di Indonesia. Sebagai bagian dari sistem hukum waris Islam, asas Keadilan Berimbang memiliki kekuatan mengikat untuk dilaksanakan dalam penentuan ahli waris yang berhak serta bagian yang akan diterima oleh masing-masing di antara mereka, terutama dalam penyelesaian sengketa waris di Pengadilan Agama. Penelitian ini menyimpulkan bahwa kekuatan mengikat Asas Keadilan Berimbang didasarkan pada beberapa argumen, yaitu:

\section{a. Asas Keadilan Berimbang Mengikat karena Bersumber dari Alquran}

Alquran, dalam lapangan hukum Islam, merupakan sumber paling fundamental sebagai dasar perumusan ketentuan hukum, termasuk di dalamnya seluruh aturan tentang hukum waris. Sebagai konsekuensi logis, maka asas Keadilan Berimbang pada tahap pertama memiliki kekuatan mengikat karena memang diatur dan menjadi bagian dari sumber hukum utama dalam hukum Islam. Pada tahap berikutnya, petunjuk hukum yang dirumuskan dalam ayat-ayat Alquran juga memiliki kekuatan mengikat berdasarkan makna yang dikandung dalam ayat-ayat hukum Alquran. Ayat-ayat hukum dimaksud digolongkan menjadi 2 (dua) kelompok yaitu ayat-ayat Qath'i dan ayat-ayat zhanni ${ }^{26}$.

Ayat-ayat tentang hukum waris tentang Asas Keadilan Berimbang, termasuk dalam kelompok ayat-ayat qath' $i .{ }^{27}$ Rangkaian ayat yang menjadi dasar Asas Keadilan Berimbang dalam surat An Nisaa ayat 11 dan 12 yang mengatur bagian anak, orang tua, serta suami atau istri dari Pewaris memenuhi karakteristik dari ayat-ayat qath' $i$, yaitu mengandung makna yang jelas dan tidak dapat ditafsirkan lain. Kedua ayat tersebut juga mengandung komponen kuantitatif melalui penyebutan nominal angka sehingga tercipta penafsiran yang sama tentang bagian yang dimaksud. Kedudukan ayat tentang Asas Keadilan Berimbang sebagai ayat qath'i berimplikasi pada kekuatan

\footnotetext{
Lihat Ahmad Azhar Basyir, 2009, Hukum Waris Islam, UII Press, Yogyakarta, hlm. 6.

Lihat Mohammad Daud Ali, 1996, Hukum Islam Pengantar Ilmu Hukum dan Tata Hukum Islam di Indonesia, PT Raja Grafindo Persada, Jakarta, hlm.79.

Makna qath'i secara etimologis diartikan sebagai definitif atau pasti, sementara secara terminologis sebagaimana yang disebutkan oleh Muhammad Hashim Kamali bahwa nash qath ' $i$ adalah nash yang jelas dan tertentu yang hanya memiliki satu makna dan tidak terbuka makna lain, sehingga hanya ada satu penafsiran dan tidak terbuka untuk penafsiran lain. Sementara makna zhanni secara etomologis diartikan sebagai spekulatif atau tidak pasti, sementara secara terminologis diartikan sebagai kebalikan dari nash qath'i dimana ayat zhanni berarti bahwa makna di dalamnya terbuka untuk penafsiran dan ijtihad.

27 Abd.Salam, "Antara Keabsolutan Nash Qath'i dan Tuntutan Keadilan (Kebimbangan antara Teologi dengan Nurani Hakim Pengadilan Agama)", dalam Sutomo dan Ahmad Zaenal Fanani, 2016, Menggugat Stagnasi Pembaruan Hukum Islam di Indonesia, UII Press, Yogyakarta.
} 
mengikat pelaksanaan ayat tersebut dalam praktik. Berdasarkan hal tersebut, peneliti menyimpulkan bahwa sebagai ketentuan qath ' $i$, maka Asas Keadilan Berimbang secara operasional yang menentukan bagian 1 (satu) orang ahli waris laki-laki sebesar bagian 2 (dua) orang ahli waris perempuan mengikat untuk diterapkan pada proses pembagian harta waris dengan tidak mengubah nominal yang telah ditentukan.

\section{b. Asas Keadilan Berimbang Mengikat karena Dikuatkan oleh Asas Hukum Waris Islam Lainnya}

Hukum waris Islam merupakan satu kesatuan sistem hukum yang terbangun atas rangkaian berbagai unsur, di antaranya rangkaian asas-asas, rangkaian definisi, rangkaian rukun, serta persyaratan hukum yang seluruhnya saling berkaitan satu dengan lainnya. Hukum waris Islam di Indonesia mengatur 10 (sepuluh) asas-asas hukum waris Islam, termasuk di dalamnya adalah asas Keadilan Berimbang. ${ }^{28}$ Pelaksanaan asas Keadilan Berimbang didasarkan pada salah satu asas, yaitu asas Ijbari.

Asas Ijbari mengatur bahwa proses peralihan harta dari Pewaris kepada Ahli waris sebagai proses langsung tanpa digantungkan kepada kehendak seseorang dan proses tersebut dilakukan sesuai ketetapan Allah SWT ${ }^{29}$ Asas Ijbari memiliki unsur memaksa atau compulsory karena proses pewarisan sudah diatur dan ahli waris menerima perpindahan harta sesuai jumlah yang telah ditentukan Allah SWT. ${ }^{30}$ Di pihak lain, Pewaris juga tidak perlu merencanakan penggunaan hartanya karena dengan kematiannya kelak, secara otomatis hartanya akan beralih kepada ahli waris dengan perolehan yang sudah ditentukan. ${ }^{31}$

Sifat paksaan atau compulsory dalam asas Ijbari dapat dilihat dari beberapa hal yaitu:

1) Sifat paksaan dalam ketentuan peralihan harta yang pasti terjadi setelah Pewaris meninggal dunia. Dasar ketentuan ini dirumuskan dalam surat $A n$ Nisaa ayat (7) sebagai berikut:

Bagi orang laki-laki ada hak bagian dari harta peninggalan ibu-bapak dan kerabatnya, dan bagi orang wanita ada hak bagian (pula) dari harta peninggalan ibubapa dan kerabatnya, baik sedikit atau banyak menurut bagian yang telah ditetapkan.

Berdasarkan kutipan di atas, pernyataan bahwa “... ada hak bagian dari harta peninggalan..." menegaskan bahwa peralihan hak atas harta akan terjadi secara langsung. Pewaris tidak perlu menjanjikan sesuatu yang akan diberikan pada ahli waris bila dia meninggal dunia dan ahli waris juga tidak perlu meminta haknya pada pewaris.

2) Sifat paksaan dalam ketentuan jumlah harta. Dasar ketentuan ini sama seperti kutipan ayat di atas, terutama pada katakata akhir bahwa "... menurut

28 Secara rinci lihat Mahkamah Agung RI Direktorat Jenderal Badan Peradilan Agama, 2010, Pedoman Pelaksanaan Tugas dan Administrasi Peradilan Agama Buku II Edisi Revisi 2010, Mahkamah Agung RI, Jakarta.

9 Lihat R. Saija dan Iqbal Taufuk, 2016, Dinamika Hukum Islam Indonesia, Deepublish, Yogyakarta, hlm. 60.

Ibid.

31 Suryati, 2017, Hukum Waris Islam, Penerbit Andi, Yogyakarta, hlm.34. 
bagian yang telah ditetapkan".

Hal ini menegaskan bahwa besar bagian harta waris yang akan diterima ahli waris memang sudah ditetapkan dalam Alquran.

3) Sifat paksaan dalam ketentuan penerima harta adalah mereka yang sudah ditentukan secara pasti. Dasar ketentuan ini ada pada ayat yang sama dengan ayat yang mengatur asas Keadilan Berimbang, terutama saat penyebutan ahli waris secara spesifik seperti penyebutan anak laki-laki, anak perempuan, bapak, ibu, suami, dan istri, sehingga disimpulkan bahwa ahli waris adalah mereka yang mempunyai hubungan darah dan ikatan perkawinan dengan Pewaris.

Sifat paksaan asas Ijbari dalam 3 (tiga) hal tersebut menguatkan kedudukan asas Keadilan Berimbang dalam system hukum waris Islam di Indonesia.

\section{c. Asas Keadilan Berimbang Mengikat karena Telah Diatur dalam Hukum Materiil Waris Islam}

Penentuan tentang hukum materiil waris Islam yang berlaku di Indonesia mengalami perkembangan dalam beberapa periode. Diawali dengan penetapan penggunaan kitab-kitab fikih yang mengacu pada mazhab syafii, berkembang pada perumusan Kompilasi Hukum Islam yang dikuatkan oleh Instruksi Presiden Nomor 1 tahun 1991 tentang Penyebarluasan Kompilasi Hukum Islam, hingga pada periode saat ini dimana hukum materiil untuk hukum waris Islam ditetapkan melalui Pedoman Pelaksanaan Tugas dan Administrasi Pengadilan yang disusun oleh Mahkamah Agung. ${ }^{32}$ Dalam ketentuan yang terakhir dirumuskan bahwa hukum materiil Peradilan Agama/ Mahkamah Syar'iyah di bidang waris adalah hukum kewarisan pada Kompilasi Hukum Islam (KHI) dan yurisprudensi yang bersumber dari Alquran, Hadis dan Ijtihad. Berdasarkan hal tersebut, maka dapat dilihat bahwa ada 2 (dua) hukum materiil hukum waris Islam yang berlaku di Indonesia, yaitu Kompilasi Hukum Islam (KHI) serta Yurisprudensi yang bersumber dari aturan pokok hukum Islam.

KHI sebagai hukum materiil memang tidak secara tegas menggunakan istilah asas Keadilan Berimbang secara tekstual. Namun asas ini menjadi pikiran dasar dalam pasalpasal pada KHI dan secara kongkrit dapat disimpulkan dari pengaturan bagian ahli waris yang berhak. Pada pasal 176 sampai dengan pasal 182, KHI menetapkan bagian masing-masing ahli waris yang berhak dengan menerapkan ahli waris laki-laki akan mendapatkan bagian lebih besar dari ahli waris perempuan. Pada pasal 176 misalnya, KHI menetapkan bahwa:

Anak perempuan bila hanya seorang ia mendapat separoh bagian, bila dua orang atau lebih mereka bersamasama mendapat dua pertiga bagian, dan apabila anak perempuan bersamasama dengan anak laki-laki, maka bagian anak laki-laki adalah dua berbanding satu dengan anak perempuan.

Pada pengaturan tentang bagian harta waris untuk janda atau duda, KHI juga mengatur bagian mereka masing-masing dengan menerapkan asas Keadilan Berimbang dengan menetapkan pada pasal 179 bahwa:

32 Lihat Destri Budi Nugraheni dan Haniah Ilhami, 2014, Perkembangan Hukum Kewarisan Islam di Indonesia, Gadjah Mada University Press, Yogyakarta, hlm. 27-39. 
Duda mendapat separoh bagian, bila pewaris tidak meninggalkan anak, dan bila pewaris meninggalkan anak, maka duda mendapat seperempat bagian.

Ketentuan tersebut diperjelas kembali pada Pasal 180 yang mengatur:

Janda mendapat seperempat bagian bila pewaris tidak meninggalkan anak, dan bila pewaris meninggalkan anak maka janda mendapat seperdelapan bagian.

Aturan pembagian harta waris secara kuantitatif tersebut merupakan rumusan yang diambil dari asas Keadilan Berimbang. KHI secara aplikatif telah menerapkan konsep bahwa seorang ahli waris laki-laki mendapatkan bagian 2 (dua) orang ahli waris perempuan melalui pengaturan pada pasalpasal tersebut. Merujuk pada fungsi dan kedudukan KHI sebagai pedoman hukum materiil, maka asas Keadilan Berimbang yang diatur dalam KHI memiliki kekuatan mengikat dalam penyelesaian pembagian harta waris berdasarkan hukum waris Islam di Indonesia. ${ }^{33}$

Ketentuan asas Keadilan Berimbang juga dikuatkan melalui sumber hukum materiil dalam bentuk yurisprudensi. Yurisprudensi dimaksud adalah Putusan Mahkamah Agung Nomor 350 K/AG/1994 tanggal 28 Mei 1997. Putusan ini mengatur bahwa dalam pembagian waris menurut hukum Islam maka harta warisan tersebut harus dibagi diantara para ahli warisnya dengan perbandingan 2 (dua) bagian bagi anak laki-laki dan 1 (satu) bagian bagi anak perempuan. ${ }^{34}$ Dengan ditetapkannya putusan ini sebagai yurisprudensi, maka hakim-hakim Pengadilan Agama menggunakan ketentuan dalam putusan tersebut sebagai salah satu sumber hukum untuk memutus perkara.

Merujuk pada hal-hal tersebut di atas, maka asas Keadilan Berimbang memiliki kekuatan mengikat dalam sistem hukum waris Islam di Indonesia. Secara fundamental mengikatnya asas Keadilan Berimbang merupakan konsekuensi logis dari ditetapkannya Alquran sebagai sumber hukum Islam di mana asas tersebut merupakan bagian dari ketentuan Alquran yang bersifat qath'i. Asas Keadilan Berimbang yang merupakan bagian dari sistem hukum waris juga mengikat dengan dikuatkan oleh asas hukum waris Islam lainnya, yaitu asas Ijbari. Pada tataran operasional, kekuatan mengikat asas Keadilan Berimbang lahir dari pengakuan KHI dan Yurisprudensi sebagai hukum materiil waris Islam yang di dalamnya telah mengaplikasikan asas tersebut ke dalam aturan konkrit.

33 Walaupun secara legal formal Instruksi Presiden Nomor 1 tahun 1991 tentang Pemberlakuan Kompilasi Hukum Islam sebagai payung hukum pemberlakuan KHI tidak termasuk dalam tata urut peraturan perundang-undangan, namun KHI tetap merupakan regulasi yang mengikat secara substantif dan secara legal formal, karena:

Mengikat secara substantif:

KHI merupakan living law serta dipandang sebagai fikih khas Indonesia yang merupakan kesepakatan para ulama Indonesia. Selain itu norma Hukum yang terkandung dalam KHI lebih bersifat peraturan perundang-undangan (regelingen) dan bukan bersifat penetapan (beschiking) Lihat Harahab, Yulkarnain dan Andy Omara, “ Kompilasi Hukum Islam dalam Perspektif Hukum Perundang-undangan”, Jurnal Mimbar Hukum, Volume 22 Nomor 3, Oktober 2010.

Mengikat secara legal formal

Kedudukan KHI secara legal formal memang ditetapkan sebagai Hukum Materiil untuk hukum waris Islam, melalui:

Keputusan Menteri Agama No. 154 tahun 1991 tentang Pelaksanaan Inpres No. 1 tahun 1991. Secara tegas, Keputusan Menteri Agama menyatakan bahwa:

"Seluruh lingkungan Instansi tersebut dalam diktum pertama, dalam menyelesaikan masalah-masalah di bidang Hukum Perkawinan, Kewarisan dan Perwakafan sedapat mungkin menerapkan Kompilasi Hukum Islam tersebut di samping peraturan perundang-undangan lainnya"

Buku II Pedoman Teknis Administrasi dan Teknis Peradilan Agama, yang diatur kedudukannya melalui Keputusan Ketua Mahkamah Agung Nomor KMA/032/SK/IV/2006 tentang Pemberlakuan Buku II Pedoman Pelaksanaan Tugas dan Administrasi Pengadilan, menyatakan secara tegas bahwa hukum materiil Peradilan Agama / Mahkamah Syari’iyah di bidang warisan adalah hukum Kewarisan KHI dan yurisprudensi yang bersumber dari Al Qur'an, Hadis, dan Ijtihad.

34 Lihat Putusan Mahkamah Agung Nomor 350 K/AG/1994 tanggal 28 Mei 1997. 
2. Kedudukan Peraturan Mahkamah Agung Nomor 3 tahun 2017 tentang Pedoman Mengadili Perkara Perempuan Berhadapan dengan Hukum dalam Penyelesaian Perkara Waris Islam

Kedudukan PERMA No.3/2017 dalam penyelesaian perkara waris Islam tidak bisa terlepas dari kedudukan Peraturan Mahkamah Agung secara umum dalam penyelesaian perkara di pengadilan. Peraturan Mahkamah Agung (selanjutnya disebut PERMA) merupakan wujud dari fungsi pengaturan (rule making power) yang diatur oleh undangundang. ${ }^{35}$ Fungsi pengaturan yang dimiliki Mahkamah Agung memberikan kewenangan pada lembaga tersebut untuk membuat peraturan sebagai pelengkap yang dalam praktik disusun dalam beberapa bentuk, yaitu Peraturan Mahkamah Agung (PERMA), Surat Edaran Mahkamah Agung (SEMA), Fatwa Mahkamah Agung, serta Surat Keputusan Ketua Mahkamah Agung (SK MA).

PERMA sebagai keputusan normatif dalam lapangan hukum acara memiliki kekuatan mengikat internal ke dalam dan berperan sebagai sebuah perangkat tingkah laku yang dimiliki Mahkamah Agung terhadap pelaksanaan fungsi peradilan dalam semua lingkungan peradilan di bawahnya. Kekuatan mengikat internal ini secara umum berlaku terhadap para hakim, jaksa, advokat, dan masyarakat pencari keadilan yang beracara di pengadilan. Namun dalam pelaksanaannya, PERMA memiliki karakteristik sendiri. Sebagai aturan internal, pelaksanaan PERMA yang ditujukan ke dalam ternyata banyak berhubungan dengan subyek-subyek lain di luar pengadilan yang akan terkait bila hendak melakukan perbuatan hukum tertentu yang melibatkan Lembaga pengadilan. ${ }^{36}$ Hal ini disebabkan oleh ruang lingkup PERMA yang mengatur proses penyelenggaraan peradilan, sehingga setiap pihak dari luar pengadilan yang akan beracara harus mengikuti pedoman dalam PERMA.

Hal yang sama juga berlaku untuk PERMA No. 3/2017. Sebagai peraturan yang bertujuan untuk memastikan penghapusan segala potensi diskriminasi terhadap perempuan yang berhadapan dengan hukum, PERMA No. 3/2017 juga dibatasi dengan ukuran yang sama. Secara substantif, PERMA No.3/2017 merupakan pedoman bagi hakim ketika memeriksa perkara yang di dalamnya ada keterkaitan dengan Perempuan Berhadapan dengan Hukum. PERMA ini mengatur setidaknya 2 (dua) kategori acuan terkait etika dan perilaku hakim saat memeriksa perkara, yaitu acuan tentang tindakan yang harus dilakukan oleh hakim dan tindakan harus dihindari ketika menghadapi perkara yang melibatkan Perempuan Berhadapan dengan Hukum. ${ }^{37}$ Melalui PERMA ini, hakim diharapkan menyelenggarakan persidangan dengan berpedoman dengan kode etik yang diatur di dalamnya.

Sebagai peraturan yang mengatur ketentuan dalam lapangan hukum formil melalui perumusan pedoman perilaku dan kode etik bagi hakim dalam menjalankan persidangan, PERMA No. 3/2017 tidak mempengaruhi hukum materiil yang digunakan dalam penyelesaian perkara, termasuk hukum materiil untuk perkara waris Islam. Hakim menggunakan PERMA No.3/2017 sebagai pedoman perilaku, bukan sebagai dasar hukum dalam pertimbangan dalam putusan maupun penetapan hakim. Hukum materiil tetap menggunakan hukum materiil yang telah ditentukan sesuai dengan jenis perkara yang diperiksa. Selain itu, kedudukan PERMA No.3/2017 sebagai aturan internal lembaga pengadilan berimplikasi pada penggunaan PERMA No.3/2017. Para pihak yang beracara

Dalam hal ini adalah Undang-undang Nomor 14 tahun 1985 tentang Mahkamah Agung sebagaimana yang telah diubah melalui UndangUndang Nomor 5 tahun 2004 Tentang Perubahan Kedua Atas Undang-Undang Nomor 14 Tahun 1985 dan Undang-Undang Nomor 3 tahun 2009 tentang Perubahan Atas Undang-Undang Nomor 14 Tahun 1985 tentang Mahkamah. Agung.

36 Lihat Ni'matul Huda, 2006, Hukum Tata Negara Indonesia, RajaGrafindo Persada, Jakarta, hlm. 71-72.

37 Penggolongan ini tidak secara eksplisit disebutkan dalam Perma dimaksud, melainkan dapat disimpulkan berdasarkan ketentuan dalam Pasal 4 dan Pasal 5 Perma No. 3 tahun 2017 tentang Pedoman Mengadili Perkara Perempuan Berhadapan dengan Hukum. 
memang ikut terikat pada PERMA tersebut dalam proses beracara, namun yang bersangkutan tidak boleh menggunakannya sebagai dasar gugatan atau permohonan. Dasar gugatan maupun permohonan tetap harus mengacu pada hukum materiil. Hal ini semakin menegaskan kekuatan mengikat secara internal bagi PERMA No.3/2017.

Penjelasan di atas menegaskan kedudukan PERMA No.3/2017 dalam penyelesaian perkara waris Islam. PERMA No.3/2017 merupakan aturan tentang pedoman perilaku dan kode etik hakim saat memeriksan perkara yang melibatkan Perempuan Berhadapan dengan Hukum. Sebagai peraturan internal, PERMA No.3/2017 hanya mengikat hakim dalam menyelenggarakan acara persidangan. Ruang lingkup PERMA No.3/2017 secara tegas hanya terbatas dalam lapangan hukum acara dan tidak mengatur hukum materiil yang telah ada.

\section{Asas Keadilan Berimbang Dikaitkan dengan Peraturan Mahkamah Agung Nomor 3 tahun 2017 tentang Pedoman Mengadili Perkara Perempuan Berhadapan dengan Hukum dalam Penyelesaian Perkara Waris Islam}

Sebagaimana yang telah dijelaskan sebelumnya, asas Keadilan Berimbang memiliki kekuatan mengikat sebagai bagian dari hukum materiil waris Islam. Bila dikaitkan dengan PERMA No.3/2017, maka pada pokoknya pemberlakuan Asas Keadilan Berimbang tidak tergantung pada PERMA No.3/2017. Secara materiil, PERMA No.3/2017 tidak mempengaruhi asas Keadilan Berimbang. Keduanya, baik PERMA No.3/2017 maupun asas Keadilan Berimbang masing-masing berdiri sendiri dan memiliki kedudukan yang berbeda. PERMA No.3/2017 yang bertujuan untuk menghapuskan segala potensi diskriminasi terhadap Perempuan Berhadapan dengan Hukum tidak bertentangan dengan konsep Asas Keadilan
Berimbang. Melalui penelitian ini, peneliti menyimpulkan beberapa alasan yang menunjukkan bahwa asas Keadilan Berimbang tidak bertentangan dengan cita-cita PERMA No.3/2017 sebagai berikut:

a. Asas Keadilan Berimbang dan Perma No.3/2017 berada dalam lapangan hukum yang berbeda

Sebagaimana yang telah dijelaskan sebelumnya, Asas Keadilan Berimbang merupakan bagian dari hukum materiil waris Islam yang berlaku dalam sistem hukum Indonesia, sementara PERMA No.3/2017 merupakan hukum formil dalam acara persidangan di pengadilan. Sebagai hukum materiil, maka asas Keadilan Berimbang merupakan hukum yang mengatur hubungan antara anggota masyarakat yang berlaku umum. ${ }^{38}$ Asas Keadilan Berimbang merupakan pedoman dalam pengaturan pemberian hak dan pembebanan kewajiban pada para ahli waris yang berhak berdasarkan hukum Islam. ${ }^{39}$ Semua ketentuan hukum waris Islam, termasuk penentuan besar bagian harta yang akan diterima ahli waris yang berhak, diatur dalam hukum materiil yang berlandaskan asas Keadilan Berimbang.

PERMA No.3/2017 yang mengatur pedoman perilaku internal dalam lingkungan peradilan, pada sisi lain berada dalam lapangan hukum formil. Sebagai bagian dari hukum formil, maka PERMA No.3/2017 mengatur tata cara penegakan hukum materiil, mengatur bagaimana melaksanakan dan menegakkan hukum materiil. Apabila dikaitkan dengan hukum materiil waris Islam, maka PERMA No.3/2017 merupakan salah satu pedoman dalam melaksanakan ketentuan yang diatur dalam hukum materiil waris Islam, termasuk melaksanakan

\footnotetext{
38 Lihat pengertian Hukum Materil dalam Marwan Mas, 2015, Pengantar Ilmu Hukum, Ghalia Indonesia, Bogor, hlm. .

39 Lihat Pengertian hukum materiil dalam Sudikno Mertokusumo, 1999, Mengenal Hukum Suatu Pengantar, Liberty, Yogyakarta, hlm. 120.
} 
ketentuan asas Keadilan Berimbang. PERMA No.3/2017 memberikan tuntunan perilaku bagi pelaksana fungsi litigasi untuk menyelenggarakan acara persidangan yang melibatkan Perempuan Berhadapan dengan Hukum guna menjamin terlaksananya hukum materiil waris Islam dengan asas Keadilan Berimbang di dalamnya.

Asas Keadilan Berimbang memang diatur dan diakomodir dalam ketentuan hukum formil acara peradilan agama, yaitu pada Buku II MA. Buku II MA sebagai pedoman beracara di pengadilan mengatur definisi tekstual dan definisi operasional Asas Keadilan Berimbang. Walaupun demikian, pengaturan tersebut sebatas pada penegasan kedudukan dan kekuatan mengikat asas Keadilan Berimbang saja. Mengingat bahwa KHI sebagai hukum materiil waris Islam memang tidak menggunakan istilah Asas Keadilan Berimbang secara tekstual, maka Buku II MA berupaya mengisi kekosongan tersebut melalui pengaturan Asas Keadilan Berimbang yang disandingkan dengan aturan lain dalam lingkup hukum acara peradilan agama.

Perbedaan kedudukan keduanya dari sudut pandang fungsi hukum menempatkan Asas Keadilan Berimbang dan PERMA No.3/2017 dalam kedudukan yang berbeda. Keduanya berdiri sendiri secara mandiri mengatur susbtansi yang berbeda. PERMA No.3/2017 tidak mengubah ataupun mempengaruhi asas Keadilan Berimbang dalam hukum waris Islam.

b. Asas Keadilan Berimbang dan Perma No. 3/2017 memiliki Substansi Hukum yang Berbeda

Selain perbedaan posisi dalamlapangan ilmu hukum, asas Keadilan Berimbang dan PERMA No.3/2017 juga memiliki substansi yang berbeda. Asas Keadilan Berimbang merupakan pedoman bagi penyusunan aturan hukum konkrit kewarisan Islam. Substansi asas ini menjelaskan tentang persamaan hak menerima harta waris serta mengatur besaran bagian masing-masing ahli waris yang berhak secara berimbang. Di dalamnya terkandung nilai-nilai keadilan berdasarkan Alquran, sekaligus juga tuntunan operasional penerapan nilai keadilan tersebut dalam hubungan horizontal antar manusia. Pikiran dasar yang terkadung di dalam asas ini kemudian dijabarkan dan dikuatkan ke dalam sistem hukum waris nasional.

PERMA No.3/2017 mengatur substansi yang berbeda. PERMA ini merumuskan pedoman bagi Hakim dalam memahami dan menerapkan kesetaraan gender dan prinsip-prinsip non-diskriminasi dalam mengadili suatu perkara. Didalamnya ditetapkan 2 (dua) kategori acuan terkait etika dan perilaku hakim saat memeriksa perkara, yaitu acuan tentang tindakan yang harus dilakukan oleh hakim dan tindakan harus dihindari ketika menghadapi perkara yang melibatkan Perempuan Berhadapan dengan Hukum selama menjalankan proses persidangan sampai dengan penyusunan putusan. Pedoman perilaku ini kemudian diharapkan dapat diterapkan oleh hakim saat menghadapi perkara terkait Perempuan Berhadapan dengan Hukum. Perbedaan substansi ini menempatkan asas Keadilan Berimbang dan PERMA No.3/2017 sebagai 2 (dua) konsep yang berbeda.

\section{c. Makna keseimbangan dalam Asas Keadilan Berimbang bermuara pada Keadilan Substansial}

Asas Keadilan Berimbang yang dijabarkan melalui ketentuan pembagian harta waris bagi anak laki-laki sebesar bagian 2 (dua) orang anak perempuan seringkali dipahami secara keliru karena dianggap sebagai aturan yang bertentangan dengan konsep kesetaraan gender. Kesetaraan gender yang diartikan sebagai kesamaan dan keseimbangan kondisi antara laki-laki dan 
perempuan untuk memperoleh kesempatan dan hak-haknya sebagai manusia agar mampu berperan dan berpartisipasi di berbagai bidang $^{40}$, dianggap tidak sejalan dengan Asas Keadilan Berimbang. Bila dikaji lebih mendalam, maka persepsi yang menyatakan bahwa Asas Keadilan Berimbang tidak sesuai dengan kesetaraan gender adalah persepsi yang keliru.

Asas Keadilan Berimbang merupakan asas yang mengandung 2 (dua) makna, yaitu makna keadilan dan makna berimbang. Dalam posisinya sebagai Asas Keadilan, asas ini mengatur kesamaan hak dan kedudukan perempuan dan laki-laki sebagai penerima harta waris. Keadilan diwujudkan melalui penegasan bahwa perbedaan gender tidak menentukan hak kewarisan dalam Islam karena Perempuan memiliki hak yang sama kuatnya dalam mendapatkan warisan sebagaimana yang didapatkan oleh lakilaki. Sementara pengertian Berimbang adalah bahwa masing-masing ahli waris akan mendapat hak yang sebanding dengan kewajiban yang dipikulnya dalam kehidupan keluarga dan masyarakat. Berdasarkan pengertian tersebut, maka indikator keseimbangan ditentukan oleh pemberian hak dan pembebanan kewajiban.

Keseimbangan hak dan kewajiban merupakan dasar penyusunan aturan pembagian harta waris. Hukum waris merupakan bagian dari sistem hukum keluarga Islam bersama dengan hukum perkawinan. Untuk itu, memahami konsepkonsep dalam hukum waris harus dengan mengikutsertakan pengertian-pengertian dalam hukum perkawinan. Keseimbangan hak dan kewajiban dalam hukum waris lahir dan merupakan kelanjutan hak dan kewajiban yang diatur dalam hukum perkawinan.
Hukum perkawinan mengatur hak dan kewajiban suami dan istri dengan berpedoman pada sumber-sumber hukum Islam. Dalam hukum perkawinan Islam, suami dibebani kewajiban materiil baik untuk kebutuhan rumah tangga maupun kebutuhan personal istri. Kewajiban ini bahkan sudah dibebankan sejak tahap paling awal dari perkawinan melalui kewajiban pembayaran mahar sebagai mana yang diatur dalam Alquran Surat An Nisaa ayat (4) berikut:

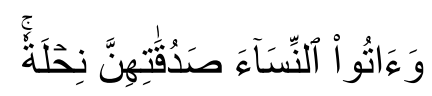

Artinya:

Berikanlah maskawin (mahar) kepada wanita (yang kamu nikahi) sebagai pemberian dengan penuh kerelaan.

Kewajiban tersebut berlanjut dalam perkawinan sebagaimana diatur dalam Alquran Surat An Nisaa ayat (34) bahwa:

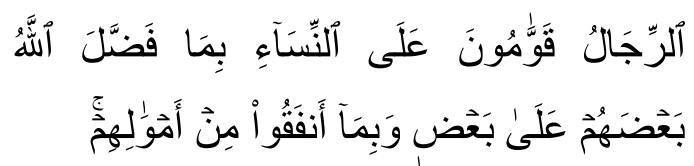

Artinya:

Kaum laki-laki itu adalah pemimpin bagi kaum wanita, oleh karena Allah telah melebihkan sebahagian mereka (laki-laki) atas sebahagian yang lain (wanita), dan karena mereka (lakilaki) telah menafkahkan sebagian dari harta mereka.

Kedua ayat tersebut merupakan dasar hukum pembebanan kewajiban seorang laki-laki sebagai suami dalam bentuk materiil yang sudah dimulai sejak awal perkawinan hingga sepanjang perkawinan tersebut berlangsung.

Hukum keluarga Islam di Indonesia juga mengatur hal yang sama. Kewajiban materiil yang dibebankan pada awal perkawinan diatur dalam Kompilasi Hukum Islam sebagai salah satu hukum materiil

40 Pasal 1 angka (4) Peraturan Mahkamah Agung No. 3 tahun 2017 tentang Pedoman Mengadili Perempuan Berhadapan dengan Hukum. 
bagi perkawinan Islam. Mahar diartikan sebagai pemberian dari calon mempelai pria kepada calon mempelai wanita, baik berbentuk barang, uang, atau jasa yang tidak bertentangan dengan hukum Islam. ${ }^{41}$ Mahar merupakan kewajiban bagi seorang suami, dan sejak saat pemberiannya ditetapkan menjadi milik pribadi istri. ${ }^{42}$ Kewajiban ini juga membuka kewenangan bagi Pengadilan Agama untuk menyelesaikan sengketa yang lahir akibat adanya selisih pendapat tentang jenis dan nilai mahar ${ }^{43}$

Sebagai kelanjutan dari kewajiban pembayaran mahar, hukum materiil perkawinan Islam juga mengatur tentang kewajiban pemenuhan nafkah yang dibebankan pada suami. Undang-undang Nomor 1 tahun 1974 tentang Perkawinan mengatur kewajiban ini melalui ketentuan bahwa suami wajib melindungi istrinya dan memberikan segala sesuatu keperluan hidup berumah tangga sesuai dengan kemampuannya. ${ }^{44}$ Kelalaian atas kewajiban ini memberikan hak kepada istri untuk mengajukan gugatan ke Pengadilan. ${ }^{45}$

Kewajiban pemenuhan kebutuhan tersebut kemudian dirinci melalui Kompilasi Hukum Islam yang mengatur: ${ }^{46}$

Sesuai dengan penghasilannya, suami wajib menanggung:

a. nafkah, kiswah dan tempat kediaman bagi isteri;

b. biaya rumah tangga, biaya perawatan dan biaya pengobatan bagi isteri dan anak;

c. biaya pendidikan bagi anak.
Pemenuhan kewajiban tersebut berlangsung selama perkawinan, bahkan dalam keadaan tertentu tetap dilanjutkan dalam jangka waktu tertentu apabila perkawinan putus akibat cerai talak. Kompilasi Hukum Islam menegaskan bahwa putusnya perkawinan karena talak tetap mewajibkan suami untuk memberikan nafkah, maskan, dan kiswah kepada bekas istri selama istri menjalani masa $i d d a h^{47}$ Berdasarkan seluruh ketentuan tersebut di atas, maka terlihat adanya kewajiban suami dalam pemenuhan kebutuhan materiil.

Merujuk pada besarnya kewajiban suami tersebut, Asas Keadilan Berimbang kemudian memberikan keseimbangan melalui pembagian bagian harta waris bagi laki-laki dengan nilai yang lebih besar yang lahir dari kewajibannya tersebut. Demi mewujudkan keadilan, maka pemberian hak harus sebanding dengan kewajiban yang diembannya. Hal ini berarti bahwa distribusi harus sebanding dengan kontribusi, dimana orang yang mempunyai tanggung jawab yang lebih berat diberi bagian yang lebih besar. Melalui kaidah tersebut, maka keadilan diwujudkan dalam bentuk kesepadanan atau keseimbangan. ${ }^{48}$

Keseimbangan antara hak dan kewajiban tersebut merupakan perwujudan dari keadilan substansial. ${ }^{49}$ Keadilan substansial adalah keadilan dalam pembagian atau penyerahan suatu hak kebendaan yang umumnya diperhitungkan dengan kalkulasi materi maupun immateri berdasarkan asas hak memperoleh keadilan. Keadilan

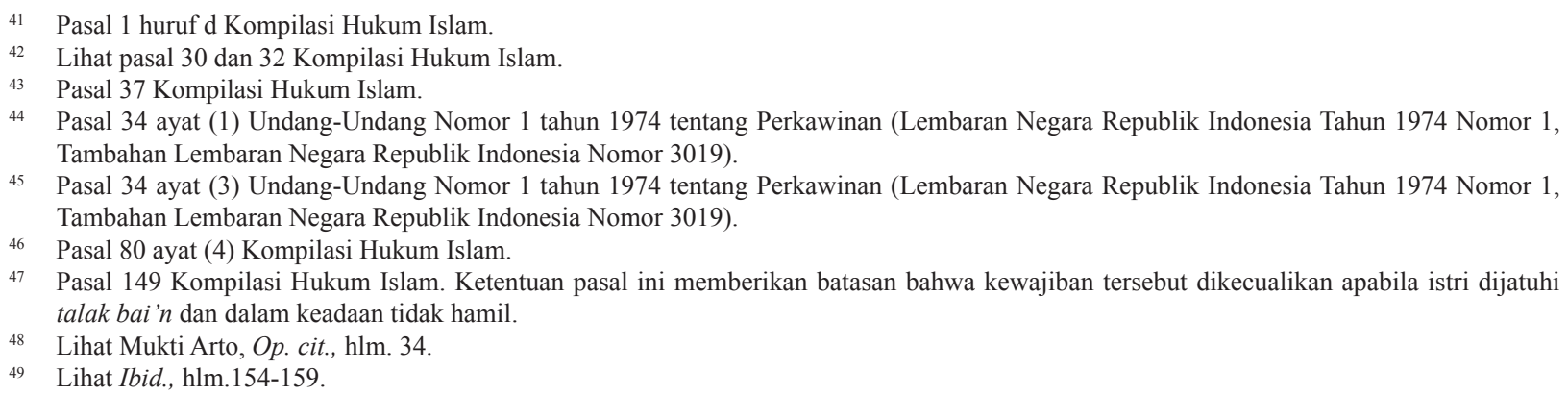


substansial merupakan salah satu tujuan akhir dari jenis perkara perdata yang diajukan pada Pengadilan Agama. ${ }^{50}$ Perkara perdata yang objeknya berupa hubungan hak dan kewajiban ini senantiasa bermuara pada keadilan substansial. Hukum yang mengatur hubungan tersebut masuk dalam kategori hukum taklifii, yaitu hukum yang mengatur hak dan kewajiban antara dua pihak berdasar asas tanggung jawab. Hubungan hak dan kewajiban merupakan satu paket keseimbangan. Tidak ada hak tanpa kewajiban dan tidak ada kewajiban tanpa hak. Keseimbangan antara keduanya merupakan muara akhir bagi penyelesaian sengketa.

Keseimbangan dalam keadilan substansial tersebutlah yang diatur melalui asas Keadilan Berimbang. Asas Keadilan Berimbang bukanlah asas yang membedakan hak atas harta waris berdasarkan perbedaan gender, bukan pula asas yang melahirkan diskriminasi terhadap perempuan. Asas Keadilan Berimbang pada hakikatnya adalah asas yang mengatur keseimbangan antara hak dan kewajiban. Nilai materi lebih banyak diberikan kepada ahli waris laki-laki adalah upaya menyeimbangkan besarnya kewajiban yang dibebankan kepadanya. Kewajiban materiil seorang laki-laki dalam rumah tangga yang berlangsung sepanjang masa perkawinan dijawab dengan pemberian hak atas harta waris yang diberikan padanya. Inilah makna dasar dari keseimbangan yang diatur dalam asas Keadilan Berimbang.

Keseimbangan hak dan kewajiban ini diakomodir dalam praktik penyelesaian perkara di Pengadilan Agama. Asas Keadilan Berimbang selalu menjadi dasar hukum utama pada setiap perkara kewarisan Islam.
Hakim selalu mencari kebenaran substantif dalam setiap perkara dengan mencari fakta tentang hak dan kewajiban yang benar-benar terjadi dalam masing-masing perkara secara kasuistis. Keadilan substansial selalu bersifat kasuistis. ${ }^{51}$ Keadilan dalam suatu kasus selalu berbeda dengan kasus yang lain karena tergantung pada karakteristik variabel yang ditemukan dalam masing-masing perkara. Dalam kasus-kasus tertentu misalnya, ditemukan bahwa suami yang berkewajiban memenuhi kebutuhan materiil rumah tangga dalam kenyataannya tidak menjalankan kewajiban tersebut. Kemudian istrilah yang berupaya mengambil alih kewajiban pemenuhan nafkah keluarga. Atau dalam kasus lain di mana seorang anak perempuan menjadi tulang punggung keluarga yang bertanggung jawab atas nafkah kedua orang tua dan anggota keluarga lainnya. Kondisi seperti inilah yang menjadi titik tolak pertimbangan hakim dalam melihat siapa pemegang kewajiban yang akan diberikan hak atas harta waris. Hakim dalam memeriksa dan mengadili sengketa harus senantiasa memperhatikan spesifikasi sengketanya. Dengan mengacu pada keseimbangan hak dan kewajiban, hakim lalu mewujudkan asas Keadilan Berimbang secara kasuistis.

\section{Kesimpulan}

Asas Keadilan Berimbang merupakan asas yang independen karena penerapan dan penegakannya tidak bergantung serta tidak bertentangan dengan prinsip Non Diskriminasi yang diatur dalam PERMA No.3/2017. Independensi Asas Keadilan Berimbang tersebut berdasarkan pada beberapa argumentasi, bahwa:

Pertama, Asas Keadilan Berimbang dan PERMA No. 3/2017 berada dalam lapangan hukum yang

50 Pengelompokkan jenis perkara perdata berdasarkan tujuan akhir yang diharapkan oleh para pihak dibagi menjadi beberapa bentuk, yaitu perkara perdata yang bertujuan untuk mendapatkan perlindungan keadilan substansial, perlindungan kemanusiaan, perlindungan kepastian hukum, perlindungan hak-hak individu, perlindungan anak, dan perlindungan harga diri. Lihat Mukti Arto, Ibid., hlm.154. 
berbeda, di mana Asas Keadilan Berimbang pada dasarnya merupakan bagian dari hukum materiil waris Islam yang berlaku dalam sistem hukum Indonesia, sementara PERMA No.3/2017 merupakan hukum formil dalam acara persidangan di pengadilan. Walaupun ketentuan Asas Keadilan Berimbang ditemukan dan diakomodir dalam ketentuan hukum formil lainnya (melalui Buku II MA), namun pengaturan tersebut sebatas pada penegasan kekuatan mengikat Asas Keadilan Berimbang dalam penyelesaian perkara waris di Pengadilan Agama

Kedua, Asas Keadilan Berimbang dan Perma No.
3/2017 memiliki substansi hukum yang berbeda. Asas Keadilan Berimbang mengatur pembagian harta waris, sementara Perma No.3/2017 mengatur pedoman perilaku hakim. Ketiga, makna keseimbangan pada Asas Keadilan Berimbang bermuara pada keadilan susbtansial. Keadilan substansial berarti bahwa ada keseimbangan antara hak dan kewajiban, dimana pemberian hak harus sebanding dengan kewajiban yang diemban. Oleh sebab itu, maka pada hakikatnya Asas Keadilan Berimbang tidak membedakan hak atas harta waris berdasarkan perbedaan gender, dan tidak melahirkan diskriminasi terhadap perempuan.

\section{DAFTAR PUSTAKA}

\section{A. Buku}

Ali, Muhammad Daud, 2011, Hukum Islam: Pengantar Ilmu Hukum dan Tata Hukum Islam di Indonesia, Rajawali Pers, Jakarta.

Arto, Mukti, 2017, Penemuan Hukum Islam Demi Mewujudkan Keadilan”, Pustaka Pelajar, Yogyakarta.

Basyir, Ahmad Azhar, 2009, Hukum Waris Islam, UII Press, Yogyakarta.

Fanani, Sutomo dan Ahmad Zaenal, 2016, Menggugat Stagnasi Pembaruan Hukum Islam di Indonesia, UII Press, Yogyakarta.

Hajar, 2017, Model-model Pendekatan dalam Penelitian Hukum dan Fiqh, Kalimedia, Yogyakarta.

Huda, Ni'matul, 2006, Hukum Tata Negara Indonesia, Raja Grafindo Persada, Jakarta.

Mahkamah Agung, MaPPI FHUI, dan AIPJ 2, 2018 , Pedoman Mengadili Perkara Perempuan Berhadapan dengan Hukum, Mahkamah Agung R.I. dan AIPJ2, Jakarta.

Mahkamah Agung RI Direktorat Jenderal Badan Peradilan Agama, 2010, Pedoman Pelaksanaan Tugas dan Administrasi Peradilan Agama Buku II Edisi Revisi 2010, Mahkamah Agung RI, Jakarta.

Mahkamah Agung, 2013, Buku II Pedoman Teknis
Administrasi dan Teknis Peradilan Agama, Mahkamah Agung R.I., Jakarta.

Marzuki, Peter Mahmud, 2011, Penelitian Hukum, Kencana Prenada Media Group, Jakarta.

Mas, Marwan, 2015, Pengantar Ilmu Hukum, Ghalia Indonesia, Bogor.

Mertokusumo, Sudikno, 1999, Mengenal Hukum Suatu Pengantar, Liberty, Yogyakarta.

Salihima, Syamsulbahri, 2015, Perkembangan Pemikiran Pembagian Warisan dalam Hukum Islam dan Implementasinya pada Pengadilan Agama, Kencana, Jakarta.

Suryati, 2017, Hukum Waris Islam, Penerbit Andi, Yogyakarta.

Sunggono, Bambang, 1997, Metodologi Penelitian Hukum, Raja Grafindo Persada, Jakarta

Syarifuddin, Amir, 2008, Hukum Kewarisan Islam, Kencana, Jakarta.

Wahid, Moh. Muhibbin dan Abdul, 2009, Hukum Kewarisan Islam sebagai Pembaruan Hukum Positif di Indonesia, Sinar Grafika, Jakarta.

Zamzami, Mukhtar, 2013, Perempuan dan Keadilan dalam Hukum Kewarisan Indonesia, Kencana, Jakarta.

\section{B. Hasil Penelitian}

Ilhami, Destri Budi Nugraheni dan Haniah Ilhami, 
2012, Hukum Terapan Kewarisan Islam dalam Sistem Hukum di Indonesia dan Penerapannya pada Pengadilan Agama di Daerah Istimewa Yogyakarta, Penelitian, Unit Penelitian dan Pengembangan Fakultas Hukum Universitas Gadjah Mada, Yogyakarta.

\section{Peraturan Perundang-undangan}

Undang-undang Nomor 1 tahun 1974 tentang Perkawinan (Lembaran Negara Republik Indonesia tahun 1974 Nomor 1, Tambahan Lembaran Negara Nomor 3019).

Undang-undang No. 14 tahun 1985 tentang Mahkamah Agung (Lembaran Negara Republik Indonesia Nomor 73 tahun 1985, Tambahan Lembaran Negara tahun 1985 Nomor 3316).

Undang-undang No. 4 tahun 2004 tentang Kekuasaan Kehakiman (Lembaran Negara Republik Indonesia Tahun 2004 Nomor 8, Tambahan Lembaran Negara Republik Indonesia Nomor 4358).

Undang-undang No. 48 tahun 2009 tentang Kekuasaan Kehakiman (Lembaran Negara Republik Indonesia Tahun 2009 Nomor 157, Tambahan Lembaran Negara Republik Indonesia Nomor 5076).
Instruksi Presiden Republik Indonesia Nomor 1 tahun 1991 tentang Penyebarluasan Kompilasi Hukum Islam (Lembaran Lepas Sekretariat Negara Tahun 1991).

Peraturan Mahkamah Agung R.I. Nomor 3 tahun 2017 tentang Pedoman Mengadili Perkara Perempuan Berhadapan dengan Hukum.

Surat Edaran Biro Pengadilan Agama Nomor B/1/735 tentang Pelaksanaan Peraturan Pemerintah Nomor 45 Tahun 1957.

Keputusan Ketua Mahkamah Agung Nomor KMA/032/SK/IV/2006 tentang Pemberlakuan Buku II Pedoman Pelaksanaan Tugas dan Administrasi Pengadilan.

Keputusan Ketua Mahkamah Agung Nomor 012/ KMA/SK/II/2007 tentang Pembentukan Tim Penyempurnaan Buku I, Buku II, Buku II dan Buku tentang Pengawasan.

\section{Putusan dan Penetapan Pengadilan}

Putusan Mahkamah Agung Nomor 350 K/AG/1994 perihal Pembagian Harta Waris dengan Perbandingan 2 (dua) Bagian bagi Anak Laki-laki dan 1 (satu) Bagian bagi Anak Perempuan, 28 Mei 1997. 